\title{
Haiti-Drill: an amphibious drilling project workshop
}

\author{
Chastity Aiken $^{1}$, Richard Wessels ${ }^{2}$, Marie-Hélène Cormier $^{3}$, Frauke Klingelhoefer ${ }^{1}$, Anne Battani ${ }^{4}$, \\ Frédérique Rolandone ${ }^{5}$, Walter Roest ${ }^{1}$, Dominique Boisson ${ }^{6}$, Kelly Guerrier ${ }^{6}$, Roberte Momplaisir ${ }^{6}$, and \\ Nadine Ellouz-Zimmerman ${ }^{7}$ \\ ${ }^{1}$ Institut Français de Recherche pour l'Exploitation de la Mer (IFREMER), Géosciences Marines, Laboratoire \\ Aléas géologiques et Dynamique sédimentaire (LAD), 29280 Plouzané, France \\ ${ }^{2}$ Faculty of Geosciences, Utrecht University, 3512 Utrecht, the Netherlands \\ ${ }^{3}$ Graduate School of Oceanography, University of Rhode Island, Narragansett, 02882 Rhode Island, USA \\ ${ }^{4}$ Isotope Geoscience Unit, SUERC, G75 0QF East Kilbride, UK \\ ${ }^{5}$ CNRS-INSU, ISTeP UMR 7193, Sorbonne Université, 75005 Paris, France \\ ${ }^{6}$ Unité de Recherche en Géosciences, Faculté des Sciences, Université d'Etat d'Haïti, \\ HT 6110 Port-au-Prince, Haiti \\ ${ }^{7}$ French Institute of Petroleum, Energies Nouvelles (IFPEN) - Direction Géosciences, \\ 92500 Rueil-Malmaison, France \\ Correspondence: Chastity Aiken (seismo.chas@gmail.com)
}

Received: 13 February 2020 - Revised: 24 June 2020 - Accepted: 20 July 2020 - Published: 1 December 2020

\begin{abstract}
The Haiti region - bounded by two strike-slip faults expressed both onshore and offshore - offers a unique opportunity for an amphibious drilling project. The east-west (EW)-striking, left lateral strike-slip Oriente-Septentrional fault zone and Enriquillo-Plantain Garden fault zone bounding Haiti have similar slip rates and also define the northern and southern boundaries of the Gonâve Microplate. However, it remains unclear how these fault systems terminate at the eastern boundary of that microplate. From a plate tectonic perspective, the Enriquillo-Plantain Garden fault zone can be expected to act as an inactive fracture zone bounding the Cayman spreading system, but, surprisingly, this fault has been quite active during the last 500 years. Overall, little is understood in terms of past and present seismic and tsunami hazards along the Oriente-Septentrional fault zone and Enriquillo-Plantain Garden fault zone, their relative ages, maturity, lithology, and evolution - not even the origin of fluids escaping through the crust is known. Given these unknowns, the Haiti-Drill workshop was held in May 2019 to further develop an amphibious drilling project in the Haiti region on the basis of preproposals submitted in 2015 and their reviews. The workshop aimed to complete the following four tasks: (1) identify significant research questions; (2) discuss potential drilling scenarios and sites; (3) identify data, analyses, additional experts, and surveys needed; and (4) produce timelines for developing a full proposal. Two key scientific goals have been set, namely to understand the nature of young fault zones and the evolution of transpressional boundaries. Given these goals, drilling targets were then rationalized, creating a focus point for research and/or survey needs prior to drilling. Our most recent efforts are to find collaborators, analyze existing data, and to obtain sources of funding for the survey work that is needed.
\end{abstract}




\section{Introduction}

Haiti-Drill, an amphibious drilling project workshop, was held in Plouzané, France, from 20 to 22 May 2019. The workshop was funded by several agencies, namely the MagellanPlus Scientific Steering Committee (SSC), the Interdisciplinary School for the Blue Planet (ISblue) program of the Université de Bretagne Occidentale, the Finistère prefecture, the Institute Français de Recherche pour l'Exploitation de la Mer (IFREMER), and the city of Brest, France. It is the second workshop held for developing an amphibious drilling project along the two strike-slip faults existing at the northern boundary of the Caribbean Plate in the Haiti region. The first MagellanPlus workshop was held in France from 26 to 28 October 2015 after preproposals were submitted earlier that same year to the International Continental Drilling Progam (ICDP) and International Ocean Drilling Program (IODP). A full amphibious drilling proposal has not yet been submitted following the 2015 workshop. Moreover, the leadership of the project, which was initially the French Institute of Petroleum Energies Nouvelles (IFPEN) and Centre Nationale de la Recherche Scientifique (CNRS), has changed to the IFREMER. Since the 2015 workshop, additional work has been done, which includes a marine deep-coring experiment (Haiti-BGF, 2015) and onshore experiments (2017, 2019); further analyses on data from marine field campaigns (Haiti-OBS, 2010; Haiti-SIS, 2012 and 2013) and onshore field campaigns $(2014,2015)$; and multichannel seismic acquisition in Lake Azuei (2017, http://projectlakeazuei.org, last access: 10 February 2020). These studies have fostered new partnerships for understanding both of the active strikeslip faults that surround Haiti and have provided new insights for prospective drilling.

Reviews of the 2015 preproposal recommended developing a stronger alignment between the objectives and drilling sites and also recommended developing a clear scientific and globally important link between the onshore and offshore targets. Thus, the primary purpose of the 2019 Haiti-Drill workshop was to identify scientific questions that link the onshore and offshore targets, based on recent results, and to enlarge the scientific participant pool. During the $2.5 \mathrm{~d}$ workshop, 34 participants from nine countries discussed recent scientific results from land and sea surveys and their implications for the development of an amphibious drilling proposal. Many of the participants in the workshop had never participated in a deep-drilling project before. Thus, one session focused on learning from past drilling experiences onshore and offshore, namely drilling strategies (e.g., management, technicalities, and policies), how to develop a successful drilling proposal, funding a drilling project, etc. In this article, we present the tectonics of the Haiti region and our research interests for an amphibious drilling project in the northern Caribbean, as well as research opportunities and our long-term plans for developing the project. The full agenda of the Haiti-Drill workshop is available at https://wwz.ifremer.fr/gm/Activites/Colloques/ Haiti-DRILL-Magellan-Plus-Workshop-May-20-22-2019 (last access: 11 July 2019).

\section{Seismotectonics of western Hispaniola}

The Gonâve Microplate is one of several blocks that make up the diffuse northern Caribbean Plate boundary, separating the Caribbean Plate in the south from the North American Plate in the north (Mann and Burke, 1984; Mann et al., 1995, 2002; Symithe et al., 2015; Calais et al., 2016). In the western part of this region the geological setting is strongly controlled by two strike-slip fault systems (Burke et al., 1978). These crustal-scale seismogenic fault systems bound a spreading center and oceanic lithosphere (Rosencrantz and Mann, 1991) and also transect and displace lithosphere affected by arc volcanism and flood basalts (Mann and Burke, 1984).

The existence of the Gonâve Microplate has been supported by seismicity along the two left lateral strike-slip faults of the northern Caribbean Plate boundary (e.g., Calais et al., 1998, 2010). The Gonâve Microplate is bounded to the south by the Enriquillo-Plantain Garden fault zone (EPGFZ), to the north by the Oriente-Septentrional fault zone (OSFZ), and to the west by the mid-Cayman spreading center (MCSC; Fig. 1). Geodetic slip rates are similar for both the EPGFZ and OSFZ; however, the velocity vector is parallel to the along strike of the OSFZ, while for the EPGFZ the velocity vector becomes more oblique onshore Hispaniola and to the east (e.g., Symithe et al., 2015; Saint Fleur et al., 2015; Calais et al., 2016). Oblique convergence along the EPGFZ is also expressed geologically as en echelon folds and thrusts adjacent to its main trace (Wang et al., 2018). The eastern boundary between the Gonâve Microplate and Hispaniola consists of a diffuse zone of deformation trending northwestsoutheast (NW-SE) through western Hispaniola (Benford et al., 2012; Symithe et al., 2015, 2016; Calais et al., 2016; see Fig. 1). Shortening between the eastern Cayman margin and Hispaniola is thought to be accommodated through a fold-and-thrust belt known as the Trans-Haitian fold-andthrust belt, which is sandwiched between the eastern segments of the EPGFZ and OSFZ (Pubellier et al., 2000). However, Wang et al. (2018) suggest there is no active folding in the Trans-Haitian Belt - only active faulting and folding along the trend of the EPGFZ. Near the Trans-Haitian Belt, the trace of the EPGFZ disappears, bringing into question whether this wedge zone is where the EPGFZ terminus is located, or if, instead, the EPGFZ is more deeply rooted without a surface expression that might connect with the Muertos Trench (Pubellier et al., 2000 and references therein). Furthermore, the EPGFZ and OSFZ strike-slip faults are characterized by alternating seismic activity on each of the fault strands (Ali et al., 2008), with historical and paleoseismic records dating back some 500 years (e.g., Bakun et al., 2012; 


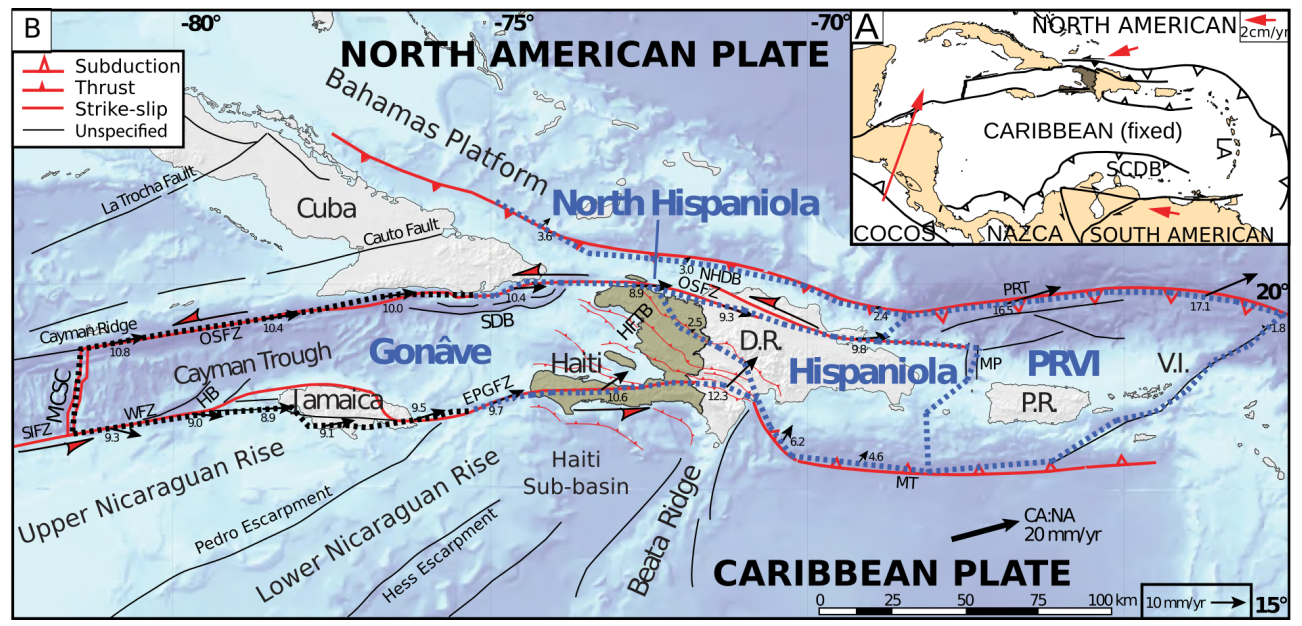

Figure 1. Map view of the Caribbean Plate northern boundary. (a) Geodynamic setting. GPS velocities (red arrows) with reference to a fixed Caribbean Plate are from DeMets et al. (2010). (b) Geodynamic setting of the northern Caribbean. Dashed lines delineate the Gonâve Microplate and Hispaniola, Puerto Rico-Virgin Islands and North Hispaniola blocks. Blue dashed lines and corresponding GPS velocity vectors are from Calais et al. (2016), while black dashed lines and corresponding GPS velocity vectors are from Symithe et al. (2015). Velocity vectors indicate the motion of the southern (western) boundary with reference to northern (eastern) boundary. Faults are modified after Leroy (1995). Caribbean-North American plate motion is from DeMets et al. (2010). Abbreviations are as follows: LA - Lesser Antilles; SCDB - South Caribbean deformed belt; SIFZ - Swan Island fault zone; MCSC - mid-Cayman spreading center; OSFZ - OrienteSeptentrional fault zone; SDB - Santiago deformed belt; NHDB - North Hispaniola deformed belt; MP - Mona Passage; PRT - Puerto Rico Trench; MT - Muertos Trough; HFTB - Haitian fold-and-thrust belt; EPGFZ - Enriquillo-Plantain Garden fault zone; HB - Hendrix pull-apart basin; WFZ - Walton fault zone; D. R. - Dominican Republic; P. R. - Puerto Rico; V. I. - Virgin Islands; and PRVI - Puerto Rico-Virgin Islands block. Modified from Wessels (2018).

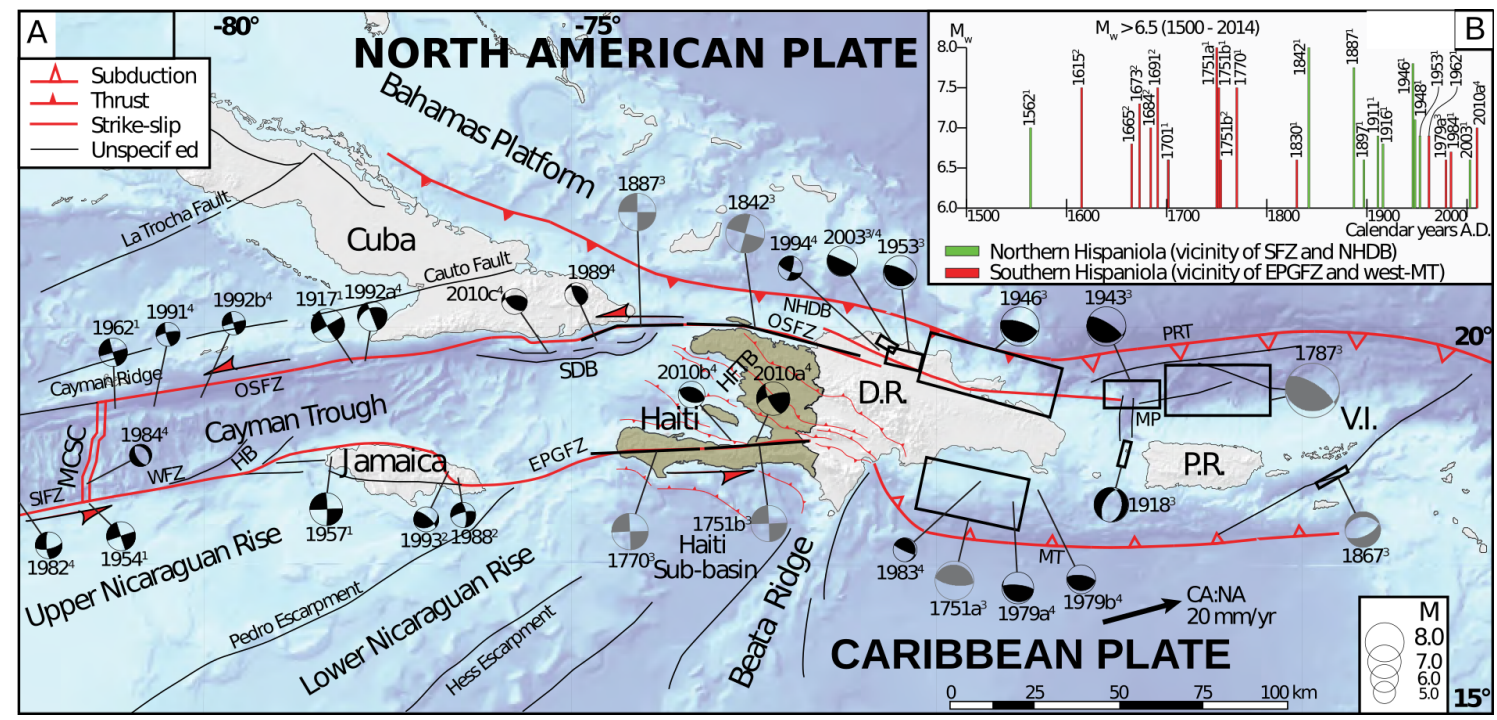

Figure 2. Historical earthquakes along the Caribbean Plate northern boundary. (a) Selection of historical and recent earthquakes. Focal mechanisms in gray are historical $\left(M_{\mathrm{W}}>7.0\right.$; pre-1900) earthquakes, and focal mechanisms in black are recorded earthquakes $\left(M_{\mathrm{W}}>5\right.$; post-1900). Sources: Van Dusen and Doser (2000), Wiggins-Grandison and Atakan (2005), Ali et al. (2008), and the International Seismological Centre (2014; $M_{\mathrm{W}}>5$; 1976-2014). (b) Earthquakes of $M_{\mathrm{W}}>6.5$ in northern Hispaniola between 1500 and 2016 . Earthquakes, in green, from northern Hispaniola and possibly linked to the offshore OSFZ and subduction at the NHDB. Earthquakes, in red, from southern Hispaniola and possibly linked to the EPGFZ or underthrusting at the MT. Sources: McCann (2006), ten Brink et al. (2011), with magnitude on intensity scale (Mi), International Seismological Centre (2014; National Earthquake Information Service - NEIS), and International Seismological Centre (2014; global centroid-moment-tensor - GCMT). Note the magnitude difference for event 1751b between McCann (2006) and ten Brink et al. (2011). Modified from Wessels (2019); same notation as Fig. 1. 
Prentice et al., 2010; ten Brink et al. 2013). It remains unclear, however, whether pure strike-slip earthquakes larger than $M 6.0$ have occurred along the onshore trace of the EPGFZ (Wessels, 2019), although small stream offsets are inferred to be a result of historically reported 18 th century earthquakes with an estimated magnitude of 7-7.6 (Prentice et al., 2010; Fig. 2). In addition, recent trenching efforts have also suggested that the EPGFZ is capable of producing magnitude $>7$ events, at least to the west of Port-au-Prince (Saint Fleur et al., 2020). Comparatively, trenching efforts along the Septentrional Fault in eastern Hispaniola suggest that events of magnitude $\sim 7$ occur at least every 800 years (e.g., Prentice et al., 2003), while others suggest recurrence intervals of just 300 years along northern Hispaniola (ten Brink et al., 2011).

Recent onshore and offshore surveys indicate that the EPGFZ and OSFZ are complex fault zones; they are highly segmented by pull-apart basins and have multiple splay faults, as evidenced by flower structures observed in seismic reflection profiles (e.g., Calais and Mercier de Lépinay, 1995; Leroy et al., 2015; Corbeau et al., 2016a; Ellouz et al., 2013; Ellouz-Zimmermann et al., 2016; Wessels et al., 2019; Wessels, 2019; and Saint Fleur et al., 2020 and references therein). Mechanically, the EPGFZ and OSFZ display various behaviors, with some segments having the potential to produce large uplift from big earthquakes (e.g., Hayes et al., 2010; Hashimoto et al., 2011; Symithe et al., 2013) and others producing deep, slow creep near the Mohorovičić (Moho) discontinuity (e.g., Peng et al., 2013; Aiken et al., 2016; see Fig. 3). However, no observable shallow creep has been expressed either geologically or in the infrastructure at the surface. In 1842, a major earthquake also occurred along the OSFZ offshore, which destroyed the cities of Cap-Haïtien and Port-de-Paix due to shaking and an induced tsunami (Scherer, 1913; Fig. 2). In 2010, Haiti was struck by a moment magnitude 7.0 earthquake near Port-au-Prince that led to one of the highest earthquake death tolls ever recorded (> 235000; Gailler et al., 2015). The tragic 2010 earthquake produced a tsunami due to coastal landslides (Hornbach et al., 2010; McHugh et al., 2011) but did not rupture the main EPGFZ fault segment in this area. The earthquake initiated on the blind north-northwest (NNW)-dipping Léogâne thrust fault, which lies just north of the EPGFZ and merges with the EPGFZ at depth (Calais et al., 2010). It is one of the en echelon structures that accommodates transpression along the EPGFZ (Saint Fleur et al., 2015; Wang et al., 2018). The 2010 earthquake highlights that stress along the EPGFZ zone is distributed among a network of faults and not a single fault plane. More recently, two earthquakes - with a magnitude 5.9 and 5.5 - occurred on 7 October 2018 along the OSFZ, just northwest of Port-de-Paix in the northern Haiti peninsula (Fig. 3). These moderate-sized earthquakes, occurring near the 1842 ruptured area, also produced thrust components based on results published in the Harvard CMT catalog. However, their relationship to the OSFZ remains unclear.

\section{Workshop discussions}

\subsection{Recent surveys and results}

Since the 2010 earthquake, a series of scientific surveys have been carried out. These include a marine deep-coring experiment (Haiti-BGF, 2015), marine field campaigns (HaitiOBS, 2010; Haiti-SIS, 2012, 2013), onshore field campaigns (2014, 2015, 2017, and 2019), and short cores and multichannel seismic acquisition in Lake Azuei (2017). Marine campaigns passively recorded the aftershocks of the $2010 M_{\mathrm{w}} 7.0$ earthquake, made high-resolution bathymetry maps, sampled sediments and fluids, and measured heat flow over the offshore western Hispaniola region. Seismic profiles from the Haiti-SIS and Haiti-SIS2 cruises in the vicinity of the EPGFZ and OSFZ conducted after the 2010 earthquake demonstrate that the EPGFZ is separated into $\sim 100 \mathrm{~km}$ long segments bordered by steep walls (Leroy et al., 2015; Corbeau et al., 2016a, b).

Actively expelled fluids (including gas) with a partial mantle origin have been documented along the onshore prolongation of the OSFZ and EPGFZ (Ellouz-Zimmermann et al., 2016). This seepage activity may significantly modify the thermal regime of the onshore fault segments. Offshore Haiti, heat flow measurements collected during the Haiti-SIS cruise provided constraints on the regional conductive heat flow (Rolandone et al., 2020). In that study, heat flow estimates from in situ measurements and bottom-simulating reflector depth suggest a regionally low heat flow in the western Hispaniola region, respectively $46 \pm 7$ and $44 \pm 12 \mathrm{~mW} \mathrm{~m}^{-2}$, with locally high values exceeding $80 \mathrm{~mW} \mathrm{~m}^{-2}$. High values were only found near the large strike-slip faults system (OSFZ and EPGFZ) or near smaller reverse faults. Because conductive mechanisms (shear heating and heat refraction) cannot explain heat flow values as high as $100-180 \mathrm{~mW} \mathrm{~m}^{-2}$, Rolandone et al. (2020) propose that fluid circulation might be the source of the fault-related high heat flow values.

Onshore, the Trans-Haiti project (2013-2014), a 27 station temporary passive seismic experiment, was conducted to determine the crustal thickness and bulk composition along a north-south coast-to-coast transect in eastern Haiti (Corbeau et al., 2017). Other onshore field campaigns include stratigraphic analysis and geological mapping, kinematic measurements, and sampling of along-fault fluids to investigate tectonic evolution, fault architecture, and paleo-fluid circulation patterns (IFPEN field campaigns, 2014, 2015, 2017). The Lake Azuei project (2017) collected a tightly spaced grid of multichannel seismic and Chirp subbottom profiles over the entire lake to image tectonic structures and also recovered three short cores for age constraints on stratigraphy. These data are intended to characterize how plate motion is partitioned between the strike-slip EPGFZ and compressional structures of the Trans-Haitian Belt, and some results from these surveys were presented at the 2019 American Geophysical Union (AGU) Fall Meeting (Charles et al., 2019; James 


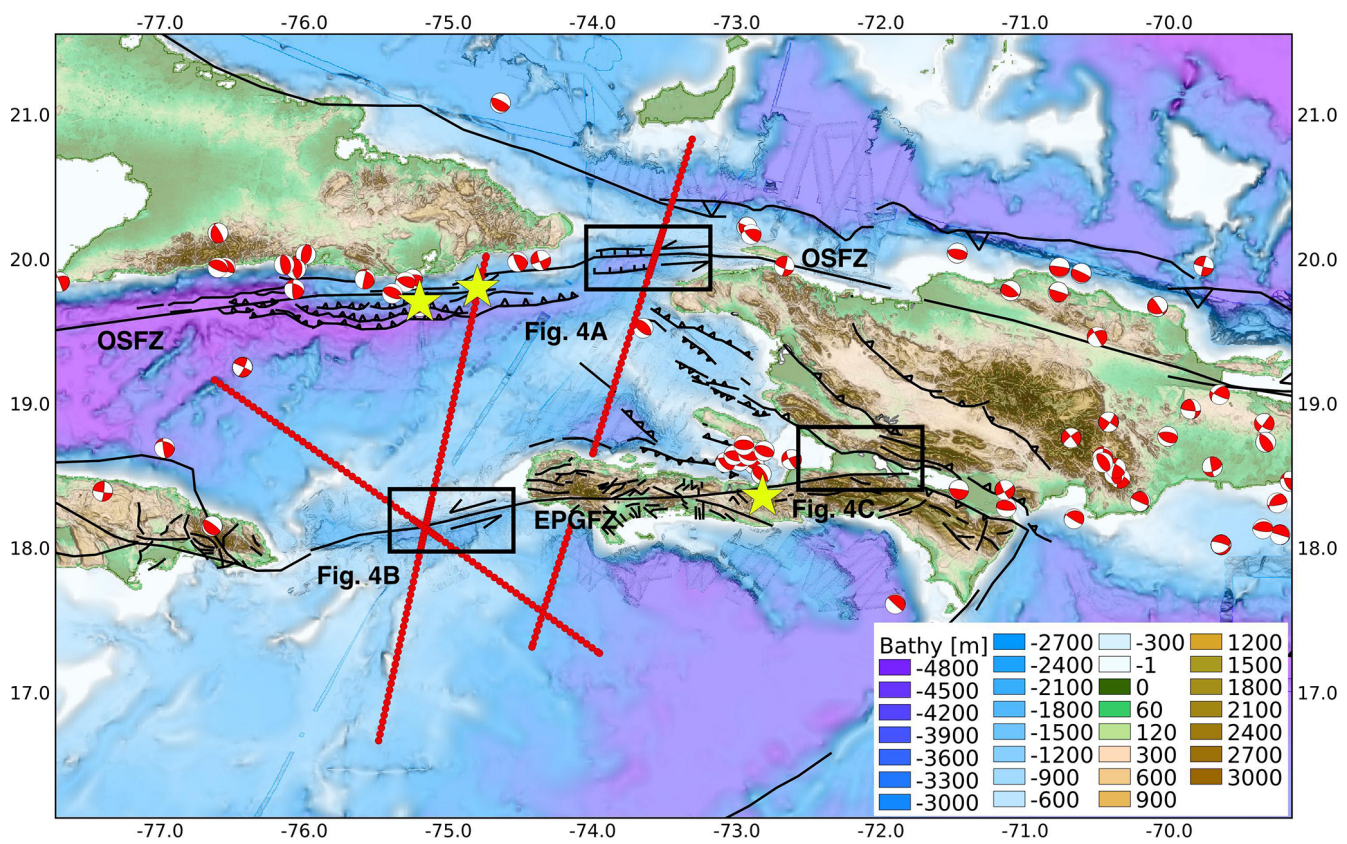

Figure 3. Recent seismotectonics of the northern Caribbean region and offshore survey plan. Red beach balls - earthquake focal mechanisms from the Harvard centroid-moment-tensor (CMT) catalog from 1976 to 2019; yellow stars - slow slip and/or tremor observations (Peng et al., 2013; Aiken et al., 2016); red profiles - proposed transects for the Haiti-TWiST cruise (see Sect. 4). The trace of the EPGFZ terminus east of Port-au-Prince, while illustrated, is actually unknown. Boxes show the locations of panels in Fig. 4.

et al., 2019). The seismic data revealed that a shallow gas front obscures much of the flat-lying turbiditic infill of the lake floor, but structures are well resolved closer to the shore. Profiles imaged a set of subtle EW-trending en echelon folds at the southeastern (SE) corner of the lake; although these folds may be associated with the presence of the EPGFZ, the seismic profiles did not image any fault scarp or stratigraphic offset. A NW-striking monoclinal fold, as wide as 3$5 \mathrm{~km}$, extends along the western shore of the lake, possibly the expression of a southwestern (SW)-dipping blind thrust fold. In addition, Aiken et al. (2016) discovered slow slip in the form of tectonic tremor on the deeper extension of the EPGFZ onshore using passive seismic data collected during both onshore and offshore campaigns (Haiti-OBS 2010) that recorded the aftershocks of the 2010 Haiti earthquake.

\subsection{Scientific perspectives}

Our overarching research interest is to provide evidence that benefits seismic hazard assessments for the Hispaniola region.

Important input parameters for seismic risk assessment include, amongst others: (a) fault characteristics, to determine the potential energy that can be released by a seismic event and the possible location and depth; (b) the geology and geomorphology of the area, to assess ground motion amplification, liquefaction, tsunami, and landslide potential; and (c) demographics and construction quality, to determine how many people are at risk and what structural loads buildings in the region can withstand. Key aspects for understanding the seismogenic behavior of faults are the fault architecture and fracture network, rheological and mechanical fault parameters, and fault fluid and gas plumbing system. These parameters can then be combined with recurrence events from paleoseismic and historical earthquake records, and geodetic slip rates, to determine the seismogenic behavior and structural maturity (e.g., Perrin et al., 2016). These types of fault characteristics have already been investigated in at least three strike-slip fault drilling expeditions, funded by the ICDP, namely the Nojima Fault in Japan, the San Andreas Fault in the USA, and the Deep Fault Drilling Project (DFDP) along the Alpine Fault in New Zealand (https://www.icdp-online.org/projects/ world/australia-and-new-zealand/alpine-fault-new-zealand/ details/, last access: 29 December 2019).

The Nojima Fault ruptured in the $1995 M_{\mathrm{JMA}}=7.2$ Hyogo-ken (Kobe) earthquake, resulting in 6400 casualties (Famin et al., 2014). Activity on this reverse dextral strikeslip fault (Boullier et al., 2004) dates back to $\sim 56 \mathrm{Ma}(\mathrm{Mu}-$ rakami and Tagami, 2004). The Nojima Fault was the target of the 1995 Nojima Fault Zone Probe project, which sought to examine the physical and chemical processes immediately following the 1995 Kobe earthquake (Ando, 2001) along the Nojima Fault of Japan, which is thought to have already initiated at least $\sim 56 \mathrm{Ma}$ (Murakami and Tagami, 2004). This expedition successfully drilled three boreholes at depths 
of $500 \mathrm{~m}$ (pilot hole), $800 \mathrm{~m}$ (passive monitoring hole), and $1800 \mathrm{~m}$ (fault penetration hole). A seismometer and thermometer were placed into the deepest borehole, which penetrated the active Kobe Fault, and water was injected into it to trigger seismicity. The drilling expedition resulted in a geological and geophysical reconstruction of the structure and evolution of the Nojima Fault, the identification of the maximum regional compressional stress axis, induced microearthquakes, and measurement of fault width from cores (e.g., Famin et al., 2014, and references therein).

The San Andreas Fault (SAF) is a dextral strike-slip system with a displacement of around $200 \mathrm{~km}$ that initiated $\sim 5 \mathrm{Ma}$ (Darin and Dorsey, 2013). Geological slip rates are estimated at $50 \mathrm{~mm} \mathrm{yr}^{-1}$ (DeMets and Dixon, 1999), while geodetic slip rates indicate a $48 \pm 5 \mathrm{~mm} \mathrm{yr}^{-1}$ (Bennett et al., 1996) right lateral offset. The San Andreas Fault Observatory at Depth (SAFOD) project targeted the SAF in the early 2000s. The SAFOD drilling project penetrated three active strands of the San Andreas Fault near Parkfield, California, a segment of the San Andreas Fault that has produced at least seven large-sized repeating earthquakes since the late 19th century. The SAFOD project had two objectives, namely to (1) investigate the physical and chemical processes that control deformation and earthquake generation within an active fault zone; and (2) make near-field observations of earthquake nucleation, propagation, and arrest to test laboratoryderived concepts about the physics of faulting (Zoback et al., 2011). A pilot borehole was drilled to $\sim 2.2 \mathrm{~km}$ depth near the terminus of the creeping section of the Parkfield segment to obtain geological and geophysical knowledge for the main SAFOD borehole (e.g., Hickman et al., 2004). A total of 27 experimental deployments were also placed in the pilot hole in preparation for a long-term observatory in the main borehole, which was drilled to a depth of $\sim 2.7 \mathrm{~km}$ (Zoback et al., 2011). The results of the SAFOD experiment are numerous, but in general, the drilling project yielded a deeper understanding of the structure and physical properties of the San Andreas Fault; the composition of fault zone rocks; the stress, temperature, and fluid-pressure conditions that nucleate earthquakes; and the absence of deep-seated fluids in fault zone processes (Zoback et al., 2011).

Based on results from previous successful ICDP strike-slip fault campaigns, drilling the OSFZ and EPGFZ can provide insight into, amongst others, the physical properties, geological evolution, and fluid-flow characteristics that are responsible for the seismogenic hazard along comparatively young, transpressive strike-slip fault zones. Although different in kinematics, complexity, age, and lithology, portions of the OSFZ and EPGFZ can both produce earthquake swarms as a form of slow slip (e.g., Possee et al., 2019) and deep creep in the lower crust (tectonic tremor; e.g., Peng et al., 2013; Aiken et al., 2016). Yet, in the Windward Passage segment of the OSFZ, deep tectonic tremor has not yet been observed, and it is still not known if escaping fluids may exist that may drive shallow earthquake swarms. In terms of phys- ical properties, the onshore part of the EPGFZ is characterized by high angles between maximum principal paleostress directions and the trace of the fault (Wessels et al., 2019), signaling a weak fault zone. However, it remains to be shown if fault weakness is observable when comparing earthquake focal mechanisms from present-day passive seismic recordings to fault orientation. Fault weakness, as is typical for the Nojima Fault and SAF (e.g., Famin et al., 2014), is either related to a very low friction coefficient or to elevated fluid pressures in the fault zone. The dominant lithology controlling the friction coefficient of the EPGFZ fault zone predominantly consists of mafic rocks (e.g., Wessels et al., 2019), which are unfortunately only exposed in a very weathered state at the surface. Samples of spring waters found proximal to the trace of the EPGFZ indicate a mantle component (Ellouz-Zimmermann et al., 2016), but these diffuse sample locations provide little insight into the fault plumbing system and fault zone fluid pressures. A receiver function study has shown that the mantle is elevated near the presumed EPGFZ (Corbeau et al., 2017), but tomographic studies did not yield any strong evidence for the presence of fluids (Possee et al., 2019). Drilling, coring, and monitoring the OSFZ and EPGFZ would result in fresh rock samples, in situ fluid chemistry and pressure measurements, and stress measurements and seismic observations in the long term. Together, these measurements provide important insights into the similarities and differences in the OSFZ and EPGFZ failure properties and, in turn, the seismogenic potential of these fault zones. In terms of recurrence intervals for the pair of strikeslip faults, we certainly lack paleorecords dating more than 500 years for which deep drilling can provide insight into their long-term seismic history. Pull-apart basins along the offshore segments of the EPGFZ and OSFZ may record activity on these faults. In addition, seismogenic lake turbidites (seismites) in lakes proximal to the onshore trace of the EPGFZ can also give estimates of earthquake recurrences. Structurally, there is the question of whether the eastern Culde-Sac-Enriquillo Valley portion of the EPGFZ terminates or continues to propagate into eastern Hispaniola. At the very least, geologic markers west of Port-au-Prince seem to indicate that the EPGFZ is eastward propagating (Saint Fleur et al., 2020). In general, propagation of strike-slip faults in heterogeneous basement terrains remains poorly understood. Drilling the EPGFZ onshore at different segments may provide insights into the propagation and maturity of this fault system.

Beyond the physical and chemical fault properties of strike-slip faults and fault propagation, we also entertained the idea that with drilling we could potentially identify whether or not a seaway closure occurred at onshore Haiti during the formation of the Cayman Trough. A paleo-reef has been identified surrounding Lake Enriquillo in the Dominican Republic (Taylor et al., 1985; Mann et al., 1995). However, there is no evidence for an equivalent reef around Lake Azuei, for which the level is 50-60 m higher than Lake 
Enriquillo. It has also been suggested that there are marine stages in both Lake Azuei and Lake Enriquillo at roughly $20 \mathrm{~m}$ below the lake bottoms (Wang et al., 2018), but this has not yet been supported by coring data. There may be evidence of ancient shells, corals, and other marine organisms in cores or samples recovered from deep drilling. These could also extend the historical record of sea surface temperature. Specifically, if a seaway closure has occurred, we might see differences in benthic foraminiferal $\mathrm{Mg} / \mathrm{Ca}$ records in Lake Azuei, compared to those observed along offshore segments of the OSFZ and the EPGFZ, as have been observed in a previous seaway closure study (Lear et al., 2003). Lake Azuei, which lies between two high mountain ranges $(>1500 \mathrm{~m})$, also provides an opportunity to address the question of how surface geology changes with climate (e.g., Whipple and Meade, 2006). Lake Azuei may even hold archaeological evidence of the time when humans first arrived on Hispaniola.

Clearly, there are many interesting questions to be asked and explored in the western Hispaniola region, both onshore and offshore. However, we determined two primary research goals for drilling as follows:

1. The nature of young fault zones - does fault weakness exist equally at different segments of the fault zones? What mechanisms control the occurrence of destructive earthquakes that can generate landslides and tsunamis? How are fluids linked to tectonic, thermal, and biogeochemical processes?

2. The evolution of transpressional boundaries - how do landscapes, hydrology, thermal regimes, and climate interact? How are atmospheric processes and lithospheric processes linked to orogeny? How do stress, strain, and fluid pressure conditions change along and across strike of juvenile, advancing transpressional fault systems?

\subsection{Drilling perspectives}

During the 2015 workshop, six drilling targets - three offshore and three onshore sites - were selected. These sites are the Windward Passage basin along the OSFZ offshore (Fig. 4a), the Navassa Basin along the EPGFZ in the Jamaica Passage (Fig. 4b), the Jérémie Basin just north of the southern peninsula, Lake Azuei (which may overlay the terminus of the EPGFZ), the EPGFZ near the southern shore of Lake Azuei, and the frontal thrust plane of the Matheux Range. Participants at the 2019 workshop agreed that basins along the OSFZ and the EPGFZ offshore remain ideal targets because they have been extensively surveyed (Haiti-SiS 2012, 2013) and require very little additional survey work. These offshore target sites are located in the releasing bends of the OSFZ and EPGFZ, where compression along the fault is expected to be lowest. Submarine pull-apart basins along strikeslip faults are capable of holding a wealth of paleoseismic records, as has been evidenced along the North Anatolian Fault system in the Sea of Marmara (McHugh et al., 2006).
On the other hand, the onshore targets identified during the 2015 workshop may not be suitable because the EPGFZ terminus fault architecture in the Lake Azuei region is still unknown, requiring additional survey work that may prove difficult. Thus, we discussed and rationalized three potential sites for onshore drilling during the workshop. We elaborate on these sites further below.

Along the EPGFZ, one potential target is near the Momance River, which follows the trace of the EPGFZ as it enters the Léogâne delta plain (Fig. 4c). This locality is $\sim 20 \mathrm{~km}$ west of Port-au-Prince and proximal to the site of the $M_{\mathrm{w}} 7.02010$ earthquake. In this area, the EPGFZ can easily be identified in the topography and is presumed to be vertical or to have a slight southern dip. At this locality, the EPGFZ juxtaposes the Caribbean large igneous province (CLIP) basement in the south against Miocene carbonate sediments in the north. Further west of the Momance River, where the EPGFZ exits the fan complex, Hornbach et al. (2010) collected Chirp high-resolution seismic profiles offshore, and Kocel et al. (2016) collected near-surface seismic reflection profiles onshore. In that region, the fan is known to be relatively thick and coarse grained with bouldersized limestones. However, we do not know the stratigraphy near the Momance River site or if it may be more conducive for drilling. Alternatively, we could consider a site just a few hundred meters offshore where high-resolution seismic data highlight the fault trace and where sediments have ponded between patch reefs (Hornbach et al., 2010). The Momance River site does provide a unique opportunity to drill through a relatively mature part of the EPGFZ to take fresh samples of the dominant crustal lithology (basalt) that this fault is penetrating and to take in situ pressure, temperature, and chemical measurements. In situ stress measurements will provide insights into the loading of the EPGFZ as a result of the 2010 earthquake, and continued monitoring would provide insights into the earthquake hazard that this fault poses. Samples from the EPGFZ onshore would be an ideal comparison to samples taken from the EPGFZ offshore, as the EPGFZ is thought to be an eastward-propagating fault (Saint Fleur et al., 2020). Differences in fault weakness may be apparent between samples, as the fault may be more mature in the west compared to the east. They could also be compared to the OSFZ, which may or may not have developed simultaneously with the EPGFZ. The benefit of this site is that the location and occurrence of the EPGFZ are certain, and the drill rig can be placed directly on (weathered) mafic basement. This site also allows a direct comparison with the outcropping core of the EPGFZ in calcareous rocks in quarries some $25 \mathrm{~km}$ eastwards along strike. It would require only a limited site survey consisting of detailed geological mapping and stratigraphic observations and perhaps even passive seismic monitoring. The difficulty with this site would be to bring the material inside this river valley and to find a large enough flat surface to install the drill rig. An alternative to this site could be the southern border of Lake Miragoâne. 

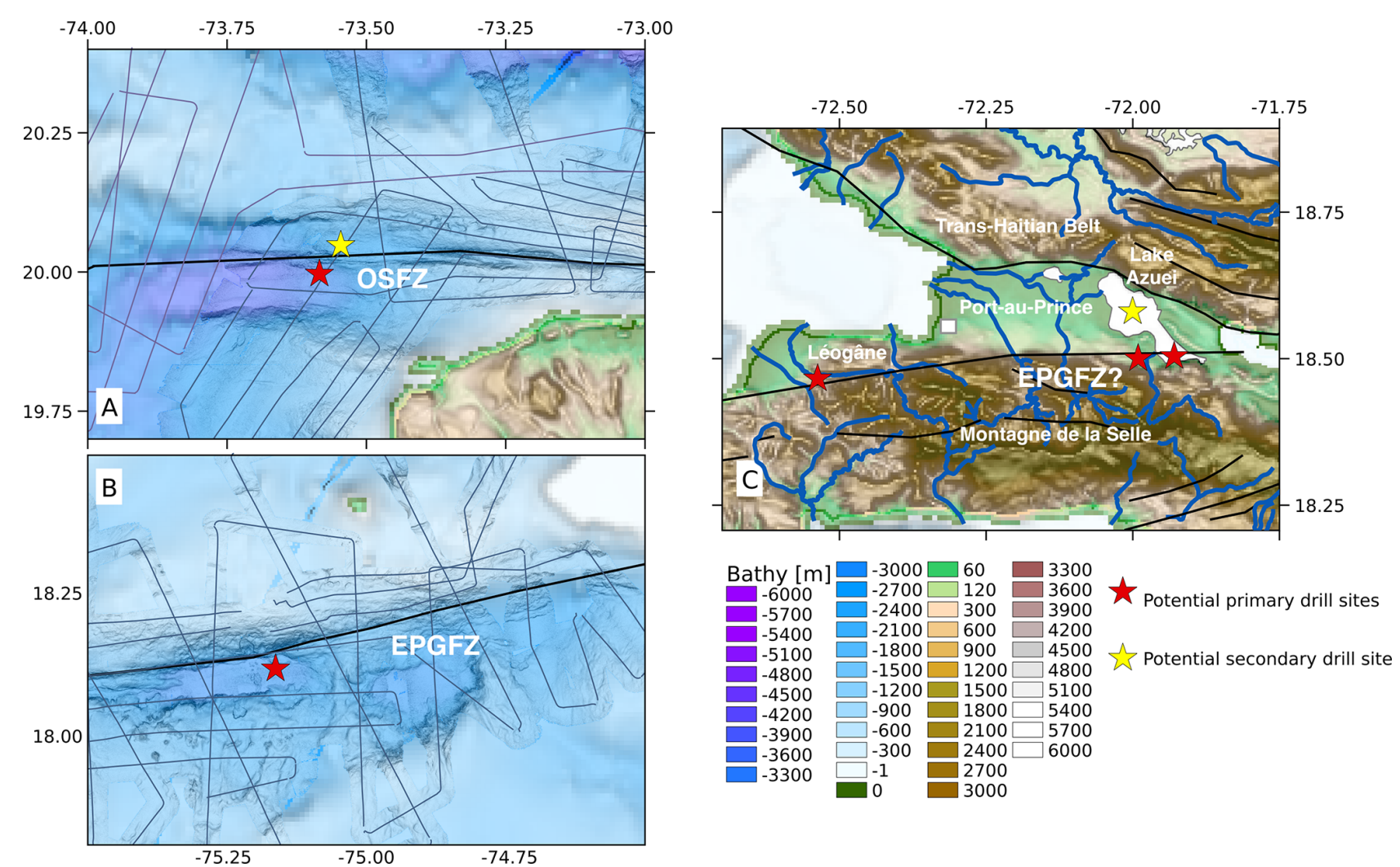

Figure 4. Potential drilling sites (red stars) and alternates (yellow stars). (a) In a basin of the Windward Passage along the OSFZ offshore the northern Haitian peninsula, (b) in the Navassa Basin of the Jamaica Passage along the EPGFZ offshore the southern Haiti peninsula and (c) onshore near the EPGFZ terminus - one site on land and one site in Lake Azuei. At the potential Momance River site, west of Port-auPrince near the Léogâne delta plain, the fault trace is better defined and the fault is also more vertical. To the east, less is known. The trace of the EPGFZ terminus east of Port-au-Prince, while illustrated in panel (c), is actually unknown, and the fault possibly dips south-southwest. The site near the Léogâne delta plain requires less additional survey work and is preferred but difficult to link scientifically to the Lake Azuei site. Multichannel seismic (MCS) data were acquired during Haiti-SIS and Haiti-SIS2 along the ship tracks, as shown in panels (a) and (b).

There are a few benefits to this site. Chirp high-resolution seismic profiles $(<10 \mathrm{~m})$ are available for Lake Miragoâne (Wang et al., 2018) and a $17 \mathrm{~m}$ core that has been thoroughly analyzed, reconstructing Caribbean climate change over the past 10500 years (Hodell et al., 1991). In addition, it would be comparatively easy to bring the drill equipment in place. The downsides are a thick alluvial sedimentary cover, less knowledge about the stratigraphy and thicknesses, a less defined fault trace, and potential fisheries in the lake.

A second potential site is the EPGFZ on the southern shore of Lake Azuei (Fig. 4c). Recent studies support a model where a large fault is likely dipping south under the Montagne de la Selle (Saint Fleur et al., 2015; Symithe and Calais, 2016; Possee et al., 2019), with diffuse deformation accommodated by various sets of oblique-slip and strike-slip faults (Wessels et al., 2019). Wang et al. (2018) suggest that the EPGFZ in this area transitions closer to vertical and is deeply buried. However, where this transition occurs is not exactly known as seismicity in the region is sparse (e.g., Possee et al., 2019), and seismic reflection surveys detailing the fault ar- chitecture are nonexistent. While there is no observable trace of the EPGFZ, this area of diffuse deformation likely represents the tip of the advancing EPGFZ. Drilling through the sequence of faults can provide insights into the distribution of stress, strain, and pressure conditions of juvenile, advancing fault systems but would provide less information about the rheological parameters controlling the fault characteristics. These characteristics could also be easily compared to characteristics observed offshore - along the OSFZ and EPGFZ to understand the differences between young fault zones and their evolution. Located directly adjacent to Port-au-Prince, investigating this segment of the EPGFZ would also benefit earthquake risk assessments in the region. However, without proper control of the location, dimensions, and thickness of splay faults, it would require a much more extensive site survey, including detailed geological mapping over a wider area, stratigraphic investigations, and possibly a seismic survey over topographically challenging terrain. Passive seismic recordings could also elucidate the fault slip mode in this region - whether creeping or locked. A benefit of this site is 
that it can be relatively easily reached when approached from the north, and it can be more easily combined with drilling in Lake Azuei compared to a project further west of Port-auPrince.

A third potential site is located within Lake Azuei (Fig. 4c). Lake Azuei, a brackish and perhaps anoxic lake (Eisen-Cuadra et al., 2013), with depths down to $30 \mathrm{~m}$ (Moknatian et al., 2017; James et al., 2019), is an ideal drilling target for a multidisciplinary drilling project. Based on recent short coring (namely, Project Lake Azuei), the sediment deposition is mostly continuous and undisturbed, and the fact that the lake is wedged between two high, active mountain ranges guarantees that it collects the by-product of mountain erosion. Therefore, the lake likely contains an exquisite sedimentary record that can be used to study paleoseismicity, paleoclimate, paleogeography, and possible even determine when humans first arrived on Hispaniola. In terms of paleoclimate, drilling Lake Azuei can extend the Holocene climate record in the northern Caribbean. Drilling here could also confirm if erosional rates are linked to drought and humid climate intervals and the influence of recent deforestation on sediment flux. The area was an open seaway during the Pliocene (e.g., Mann et al., 1984), but the timing of the closure of that seaway remains to be documented. Because Lake Azuei is probably anoxic at its depocenter (Fig. 4c, yellow star), it should preserve a pristine stratigraphy (not bioturbated). Its sediments may thus host a detailed climate record and earthquake record and may also allow one to precisely date the arrival of humans on Hispaniola based on detailed pollen and charcoal analysis. Finally, Lake Azuei lies near the presumed terminus of the EPGFZ, which may hold information about paleoseismic records. With influx from distinctly different sources (basements) in the north and south, it is potentially possible to distinguish between earthquakes triggering seismites in central versus southern Hispaniola. Paleoseismic records from Lake Azuei would also make a desirable scientific link between drilling onshore and offshore - giving historical records of earthquake activity along the OSFZ and EPGFZ that can provide clues to the evolution of the dual strike-slip system. Lastly, multichannel seismic profiles faintly imaged a deformation zone present beneath the shallow gas front and that extends across a $2-3 \mathrm{~km}$ wide corridor paralleling the southern shore of the lake. However, it remains unclear whether this deformed layer reflects faulting and/or folding. Drilling into those deformed rocks may provide a useful test with respect to the competing models for the nature of the EPGFZ in that area.

\section{Future plans}

The future of the Haiti-Drill project was discussed on the last day of the workshop. It was agreed that there are three imperative tasks for producing a successful amphibious drilling project in the western Hispaniola region. First, more prelimi- nary work should be done, especially for the onshore sites. Second, we need additional expertise to analyze existing data and diversify the science related to drilling. Third, local Haitian researchers and students must be included in smallscale projects leading up to the drilling proposal to build training, understanding, and community support. We identified additional data, research, surveys, and scientists needed in order to develop a future proposal. Finally, we created realistic timelines for both onshore and offshore projects.

Despite several oceanographic surveys conducted within the last decade, some questions still remain about the architecture of the OSFZ and EPGFZ offshore. In particular, the dipping angles of the OSFZ and EPGFZ target areas are not well constrained, which is required for selecting the ICDP and IODP sites. A marine deep seismic cruise proposal (namely, Haiti-TWiST) was submitted in September 2019 to investigate the structural and mechanical behaviors of the OSFZ and EPGFZ offshore and target the offshore drilling sites (Fig. 3) and was successfully classed as being a top priority for scheduling from 2021. During this campaign, we will conduct a wide-angle seismic reflection survey offshore Haiti, take heat flow measurements, sediment cores, and sample interstitial fluids across the fault zones near the drilling target sites to characterize the possible hydrothermal system and make passive seismic recordings near the fault zones to observe the different types of seismicity. The wideangle seismic survey will constrain the fault structure, sediment coring across and along the faults will help constrain paleoseismic records, and fluid sampling will help to understand their origins and relationship with present-day seismicity on passive seismic recordings. Onshore, the 2017 marine seismic survey of Lake Azuei revealed the presence of a diffuse gas front in the shallow sediments, except for its deepest basin floor. A deformation zone is visible below the gas front along the presumed extension of the EPGFZ in the southern part of the lake (Charles et al., 2019). Although, at this stage of data processing, it remains unclear whether that deformation zone reflects folding or faulting. If deeper pockets of pressurized gas exist, this would prevent drilling for safety reasons.

The other potential onshore targets, south of Lake Azuei and along the Momance River or the alternative site on the southern border of Lake Miragoâne require additional site surveys. While the Momance River requires only limited additional geological mapping and refining of the local stratigraphy, Lake Miragoâne and the onshore site near Lake Azuei's southern shore require extensive site surveys; additional reflection seismics to determine the location and geometry of the faults necessary for developing a drilling plan are needed. However, at present, we have no single onshore site that is preferred because there have not been any multidisciplinary studies conducted at any one site that can support drilling at this time. If survey work is successful, we would prefer to target Lake Azuei and land near the southern shore of Lake Azuei as these sites would be more easily 
linked due to their locations and because Lake Azuei offers a potential wealth of multidisciplinary data. However, near the southern shore of Lake Azuei, topography may present a problem for site surveys. We are currently in the process of planning a multidisciplinary onshore survey project for submission to the Agence Nationale de la Recherche (ANR) for funding. The project will target sites west of Lake Azuei and near the Momance River so that we can choose the best drilling location. Surveys will be conducted in collaboration with scientists from the Université d'Etat d'Haït. The surveys will serve as fieldwork opportunities for Haitian students from the Université d'Etat d'Haïti. However, finding a sufficiently powerful seismic source to conduct a seismic reflection survey with a penetration depth $>1 \mathrm{~km}$ will likely be more challenging.

While more data need to be collected to justify drilling offshore, there are also many research opportunities for organic and/or inorganic geochemists, sedimentologists, paleoseismologists, paleoecologists, and biogeochemists to explore existing data and/or participate in the future drilling project. For example, $2 \sim 80 \mathrm{~cm}$ long cores were collected in 2017 from Lake Azuei (http://projectlakeazuei.org, last access: 10 February 2020) with several intervals that have been dated with radioisotope methods (Cormier et al., 2018). Some cores offshore were taken during the Haiti-BGF and first Haiti-SIS cruise, but the data were insufficient to decide whether fluid is escaping or not. Cores from these campaigns were scarce and often short and did not provide any fluid geochemistry indicative of strong circulation. However, this of course does not prove that there are no fluids escaping along fault offshore. Other investigations, e.g., acoustic measurements in the water column, are needed to find places where seeps occur and other and longer cores, if possible something we aim to address in the Haiti-TWiST marine campaign. Onshore, there is evidence of advected mantlederived fluids, but more samples are needed to assess the temporal variability. We are also searching for additional researchers to assist with developing the paleorecord from the short cores (onshore and offshore). Moreover, this project is a unique opportunity for paleoclimate studies as Lake Azuei lies between two topographic highs and likely has erosional deposits. In particular, Lake Azuei appears to be anoxic at its depocenter, which makes for an ideal drilling target for paleoclimate studies. It may also be archiving key markers (such as maize pollens) that may have recorded when humans arrived in Hispaniola.

\section{Concluding remarks}

The western Hispaniola region presents a unique opportunity for an amphibious drilling project because it is bounded by two active strike-slip faults with the potential for vertical uplift onshore and offshore. In addition, the EPGFZ and OSFZ are both younger than previously drilled strike-slip faults, which makes drilling in the western Hispaniola region ideal for not only expanding our understanding of the physical and chemical properties of strike-slip faults at different stages of maturity but also for providing samples of a potentially propagating fault system.

During the 2019 Haiti-Drill workshop, we discussed themes such as the evolution of transpressional boundaries - how landscapes, hydrology, thermal regimes, and climate interact - and the nature of young fault zones. We identified key questions that link the onshore and offshore segments of the dual strike-slip system and made some preliminary drilling-scenario plans. Our research goals are largely related to seismotectonics - understanding how the OSFZ and EPGFZ strike-slip faults have evolved and their characteristics - how have they behaved in the past, how they behave today, and what controls that behavior. We have yet to decide how we will approach drilling - whether drilling through faults is possible or if we must drill next to the faults. Deciding this requires additional research, surveys, and expertise. In particular, high-resolution, wide-angle seismic reflection, geological mapping, heat flow measurements, and additional coring need to be done to enhance our understanding of the architecture, hydrothermal systems, and paleorecord of the region prior to deeper drilling. At least one deep marine survey has been planned, and funding for onshore surveys is currently being sought. At present, there are existing cores and seismic data that need additional analyses. We are specifically interested in enlarging the scientific team to help with additional analyses, future field work, and the long-term development of the full proposal. Anyone interested in access to data or participating in the long-term development of the amphibious drilling project is invited to contact Chastity Aiken, the corresponding author.

Data availability. All data are from third parties. Data for Fig. 1 are from DeMets et al. (2010). Data for Fig. 2 are from McCann (2006), ten Brink et al. (2011), and the International Seismological Centre (ISC). Earthquakes listed in the ISC catalog are openly available (http://www.isc.ac.uk, last access: 27 August 2020). Focal mechanisms shown in Figs. 2 and 3 are openly available from the Harvard Global Centroid Moment Tensor Catalog (GCMT; https://www.globalcmt.org/CMTsearch.html, last access: 27 August 2020). Ship track information shown in Fig. 4 is not openly accessible but is available upon request from the corresponding author.

Author contributions. NEZ conceived the idea for an amphibious drilling project onshore and offshore Haiti. CA improved upon the amphibious drilling project idea in this workshop report with contributions from all authors. CA, RW, and FK collected the data presented in Figs. 1-4. CA, RW, MHC, FK, AB, FR, WR, and NEZ contributed to the writing of the paper. $\mathrm{DB}, \mathrm{KG}$, and RM provided direction, advice, and feedback on this paper, which is necessary for this future drilling project to be successful. 
Competing interests. The authors declare that they have no conflict of interest.

Acknowledgements. We extend our special thanks to Manuel Pubellier of École normale supérieure (ENS) - one of the initiators of this amphibious scientific drilling project aiming to better understand active faults in the Haiti region - and to Paul Mann, Jamie Austin, and one anonymous reviewer for their thoughtful reviews that enhanced the quality of this paper. The authors also express their sincere gratitude to the MagellanPlus SSC, Université de Bretagne occidentale, the Finistère prefecture, the Institute Français de Recherche pour l'Exploitation de la Mer (IFREMER), and the city of Brest, France, for financially supporting the 2019 Haiti-Drill workshop. In particular, this workshop was supported in part by ISblue, the "Interdisciplinary graduate school for the blue planet", a project cofinanced (grant no. ANR17-EURE-0015) and administered by the French national research agency, ANR, within the French State program of Investments For The Future (PIA).

Review statement. This paper was edited by Will Sager and reviewed by Paul Mann, James A. Austin, and one anonymous referee.

\section{References}

Aiken, C., Chao, K., Gonzalez-Huizar, H., Douilly, R., Peng, Z., Deschamps, A., Calais, E., and Haase, J. S.: Exploration of remote triggering: A survey of multiple fault structures in Haiti, Earth Planet. Sc. Lett., 455, 14-24, https://doi.org/10.1016/j.eps1.2016.09.023, 2016.

Ali, S. T., Freed, A. M., Calais, E., Manaker, D. M., and McCann, W. R.: Coulomb stress evolution in Northeastern Caribbean over the past 250 years due to coseismic, postseismic and interseismic deformation, Geophys. J. Int., 174, 904-918, https://doi.org/10.1111/j.1365-246X.2008.03634.x, 2008.

Ando, M.: Geological and geophysical studies of the Nojima Fault from drilling: An outline of the Nojima Fault Zone Probe, Isl. Arc, 10, 206-214, https://doi.org/10.1111/j.14401738.2001.00349.x, 2001.

Bakun, W. H., Flores, C. H., and ten Brink, U. S.: Significant earthquakes on the enriquillo fault system, Hispaniola, 1500-2010: implications for seismic hazard, B. Seismol. Soc. Am., 102, 1830, https://doi.org/10.1785/0120110077, 2012.

Benford, B., DeMets, C., and Calais, E.: GPS estimates of microplate motions, northern Caribbean: evidence for a Hispaniola microplate and implications for earthquake hazard, Geophys. J. Int., 191, 481-490, https://doi.org/10.1111/j.1365246X.2012.05662.x, 2012.

Bennett, R., Rodi, W., and Reilinger, R. E.: Global Positioning System constraints on fault slip rates in southern California and northern Baja, Mexico, J. Geophys. Res., 101, 21943-21960, https://doi.org/10.1029/96JB02488, 1996.

Boullier, A.-M., Fujimoto, K., Ito, H., Ohtani, T., Keulen, N., Fabbri, O., Amitrano, D., Dubois, M., and Pezard, P.: Structural evolution of the Nojima fault (Awaji Island, Japan) revisited from the GSJ drill hole at Hirabayashi, Earth Planets Space, 56, 1233 1240, https://doi.org/10.1186/BF03353345, 2004.

Burke, K., Fox, P. J., and Sengör, A. M. C.: Buoyant ocean floor and the evolution of the Caribbean, J. Geophys. Res., 83, 3949-3954, https://doi.org/10.1029/JB083iB08p03949, 1978.

Calais, E. and Mercier de Lépinay, B.: Strike-slip tectonic processes in the northern Caribbean between Cuba and Hispaniola (windward passage), Mar. Geophys. Res., 17, 63-95, https://doi.org/10.1007/BF01268051, 1995.

Calais, E., Perrot, J., and Mercier de Lépinay, B.: Strike-slip tectonics and seismicity along the northern Caribbean plate boundary from Cuba to Hispaniola, Geol. Soc. Am. Soc., 326, 125-169, https://doi.org/10.1130/0-8137-2326-4.125, 1998.

Calais, E., Freed, A., Mattioli, G., Amelung, F., Jónsson, S., Jansma, P., Hong, S.-H., Dixon, T., Prépetit, C., and Momplaisir, R.: Transpressional rupture of an unmapped fault during the 2010, Haiti earthquake, Nat. Geosci., 3, 794-799, https://doi.org/10.1038/ngeo992, 2010.

Calais, E., Symithe, S., Mercier de Lépinay, B., and Prépetit C.: Plate boundary segmentation in the northeastern Caribbean from geodetic measurements and Neogene geological observations, C. R. Geosci., 348, 42-51, https://doi.org/10.1016/j.crte.2015.10.007, 2016.

Charles, N., Cormier, M.-H., Sloan, H., Wattrus, N. J., Sorlien, C. C., Boisson, D., Guerrier, K., Hearn, C. K., King, J. W., Momplaisir, R., Symithe, S. J., and Ulysse, S. M. J.: Multichannel Seismic Survey of Lake Azuei (Haiti) Documents a Complex System of Active Transpressional Structures Across the North American-Caribbean Plate Boundary, Fall Meeting Am. Geophysical Union, 9-13 December 2019, San Francisco, USA, abstract no. 555543, https://doi.org/10.1002/essoar.10501580.1, 2019.

Corbeau, J., Rolandone, F., Leroy, S., Mercier de Lépinay, B., Meyer, B., Ellouz-Zimmermann, N., and Momplaisir, R.: The northern Caribbean plate boundary in the Jamaica Passage: Structure and seismic stratigraphy, Tectonophysics, 675, 209226, https://doi.org/10.1016/j.tecto.2016.03.022, 2016 .

Corbeau, J., Rolandone, F., Leroy, S., Meyer, B., Mercier de Lépinay, B., Ellouz-Zimmermann, N., and Momplaisir, R.: How transpressive is the northern Caribbean plate boundary, Tectonics, 35, 1032-1046, https://doi.org/10.1002/2015TC003996, $2016 b$.

Corbeau, J., Rolandone, F., Leroy, S., Guerrier, K., Keir, D., Stuart, G., Clouard, V., Gallacher, R., Ulysse, S., Boisson, D., Momplaisir R. B.-A., Saint Preux, F., Prépetit, C., Saurel, J.-M., Mercier de Lépinay, B., and Meyer, B.: Crustal structure of western Hispaniola (Haiti) from a teleseismic receiver function study, Tectonophysics, 709, 9-19, https://doi.org/10.1016/j.tecto.2017.04.029, 2017.

Cormier, M.-H., Sloan, H., King, J. W., Boisson, D., Guerrier, K., Hearn, C. K., Heil, C. W., Kelly, R. P., Momplaisir, R., Murray, A. N., Sorlien, C. C., Symithe, S. J., Ulysse, S. M. J., and Wattrus, N. J.: Late Quaternary Fault-Related Folding, Uplifted Paleoshoreline, and Liquefaction Structures: Clues About Transpressional Activity Along the North America-Caribbean Plate Boundary From a Comprehensive Seismic Reflection Survey of Lake Azuei, Haiti, Fall Meeting Am. Geophys. Union, 10 14 December 2018, Washington, DC, USA, Poster EP51D-0692, https://doi.org/10.1002/essoar.10500232.1, 2018. 
Darin, M. and Dorsey, R.: Reconciling disparate estimates of total offset on the southern San Andreas Fault, Geology, 41, 975-978, https://doi.org/10.1130/G34276.1, 2013.

DeMets, C. and Dixon, T.: New kinematic models for Pacific-North America motion from 3 Ma to present, I: Evidence for steady motion and biases in the NUVEL-1A model, Geophys. Res. Lett., 26, 1921-1924, https://doi.org/10.1029/1999GL900405, 1999.

DeMets, C., Gordon, R. G., and Argus, D. F.: Geologically current plate motions, Geophys. J. Int., 181, 1-80, https://doi.org/10.1111/j.1365-246X.2009.04491.x, 2010.

Eisen-Cuadra, A., Christian, A. D., Dorval, E., Broadaway, B., Herron, J., and Hannigan, R. E.: Metal Geochemistry of a Brackish Lake: Étang Saumâtre, Haiti, Medical Geochemistry, Springer Netherlands, 149-166, https://doi.org/10.1007/978-94007-4372-4_9, 2013.

Ellouz, N., Leroy, S., Momplaisir, R., Mercier de Lépinay, B., and the Haiti-SIS group: From 2012 Haiti-SIS Survey: Thick-skin versus thin-skin tectonics partitioned along offshore strike-slip faults - Haiti, Fall Meeting Am. Geophys. Union, 9-13 December 2013, San Francisco, California, USA, Poster T23E-2648, 2013.

Ellouz-Zimmermann N., Hamon, Y., Deschamps, R., Battani, A., Darnault, R., and Pillot, D.: Rapport intermédiaire des observations terrain et analyses dans le système transpressif d'Haiti, Projet collaboratif Haiti-Faille, Rapport ref: 65948, 2016 (in French).

Famin, V., Raimbourg, H., Garcia, S., Bellahsen, N., Hamada, Y., Boullier, A.-M., Fabbri, O., Michon, L., Uchide, T., Ricci, T., Hirono, T., and Kawabata, K.: Stress rotations and the long-term weakness of the Median Tectonic Line and the Rokko- Awaji Segment, Tectonics, 33, 1900-1919, https://doi.org/10.1002/2014TC003600, 2014.

Gailler, A., Calais, E., Hébert, H., Roy, C., and Okal, E.: Tsunami scenarios and hazard assessment along the northern coast of Haiti, Geophys. J. Int., 203, 2287-2302, https://doi.org/10.1093/gji/ggv428, 2015.

Hashimoto, M., Fukushima, Y., and Fukahata, Y.: Fan-delta uplift and mountain subsidence during the 2010 Haiti earthquake, Nat. Geosci., 4, 255-259, https://doi.org/10.1038/ngeo1115, 2011.

Hayes, G., Briggs, R., Sladen, A., Fielding, E. J., Prentice, C., Hudnut, K., Mann, P., Taylor, F. W., Crone, A. J., Gold, R., Ito, T., and Simons, M.: Complex rupture during the 12 January 2010 Haiti earthquake, Nat. Geosci., 3, 800-805, https://doi.org/10.1038/ngeo977, 2010.

Hickman, S., Zoback, M., and Ellsworth, W.: Introduction to special section: Preparing for the San Andreas Fault Observatory at Depth, Geophys. Res. Lett., 31, L12S01, https://doi.org/10.1029/2004GL020688, 2004.

Hodell, D. A., Curtis, J. H., Jones, G. A., Higuera-Gundy, A., Brenner, M., Binford, M. W., and Dorsey, K. T.: Reconstruction of Caribbean climate change over the past 10500 years, Nature, 352, 790-793, https://doi.org/10.1038/352790a0, 1991.

Hornbach, M., Braudy, N., Briggs, R. W., Cormier, M.-H., Davis, M. B., Diebold, J. B., Dieudonne, N., Douilly, R., Frohlich, C., Gulick, S. P. S., Johnson III, H. E., Mann, P., McHugh, C., Ryan-Mishkin, K., Prentice, C. S., Seeber, L., Sorlien, C. C., Steckler, M. S., Symithe, S. J., Taylor, F. W., and Templeton, J.: High tsunami frequency as a result of combined strike- slip faulting and coastal landslides, Nat. Geosci., 3, 783-788, https://doi.org/10.1038/ngeo975, 2010.

International Seismological Centre: On-line Bulletin, available at: http://www.isc.ac.uk (last access: 27 August 2020), 2014.

James, K., Cormier, M.-H., Sloan, H., Ramsamooj, T., Boisson, D., Guerrier, K., Hearn, C. K., King, J. W., Momplaisir, R., Symithe, S. J., Ulysse, S. M. J., and Wattrus, N. J.: Geomorphologic and Stratigraphic Evidence of Ongoing Transpressional Deformation Across Lake Azuei (Haiti), Fall Meeting Am. Geophysical Union, 9-13 December 2019, San Francisco, California, USA, abstract T31D-0268, https://doi.org/10.1002/essoar.10501568.1, 2019.

Kocel, E., Stewart, R. R., Mann, P., and Chang, L.: Nearsurface geophysical investigation of the 2010 Haiti earthquake epicentral area: Léogâne, Haiti, Interpretation, 4, T49-T61, https://doi.org/10.1190/INT-2015-0038.1, 2016.

Lear, C. H., Rosenthal, Y., and Wright, J. D.: The closing of a seaway: ocean water masses and global climate change, Earth Planet. Sc. Lett., 210, 425-436, https://doi.org/10.1016/S0012821X(03)00164-X, 2003.

Leroy, S.: Structure et origine de la Plaque Caraïbe: implications géodynamiques, Dissertation, Université Pierre et Marie Curie, Paris, 240 pp., available at: https://www.semanticscholar. org/paper/Structure-et-origine-de-la-plaque-caraibe-Leroy/ bc7ee1fdcd05c13ec40628041d70a511dff29cbe (last access: 27 August 2020), 1995.

Leroy, S., Ellouz-Zimmermann, N., Corbeau, J., Rolandone, F., Mercier de Lépinay, B., Meyer, B., Momplaisir, R., Granja Bruña, J.L., Battani, A., Baurion, C., Burov, E., Clouard, V., Deschamps, R., Gorini, C., Hamon, Y., Lafosse, M., Leonel, J., Le Pourheit, L., Llanes, P., Loget, N., Lucazeau, F., Pillot, D., Poort, J., Tankoo, K. R., Cuevas, J.-L., Alcaide, J.F., Jean, P., Munoz-Martin, A., Mitton, S., Rodridguez, Y., Schmitz, J., Seeber, L., Carbo-Gorosabel, A., and Munoz, S.: Segmentation and kinematics of the North American-Caribbean plate boundary offshore Hispaniola, Terra Nova, 27, 467-478, https://doi.org/10.1111/ter.12181, 2015.

Mann, P. and Burke, K.: Neotectonics of the Caribbean, Rev. Geophys., 22, 309-362, https://doi.org/10.1029/RG022i004p00309, 1984.

Mann, P., Taylor, F. W., Edwards, R. L., and Ku, T. L.: Actively evolving microplate formation by oblique collision and sideways motion along strike slip faults: An example from the northwestern Caribbean plate margin, Tectonophysics, 246, 1-69, https://doi.org/10.1016/0040-1951(94)00268-E, 1995.

Mann, P., Calais, E., Ruegg, J.-C., DeMets, C., Jansma, P.E., and Mattioli, G.S.: Oblique collision in the northeastern Caribbean from GPS measurements and geological observations, Tectonics, 21, 7-1-7-26, https://doi.org/10.1029/2001TC001304, 2002.

McCann, W. R.: Estimating the threat of tsunamigenic earthquakes and earthquake induced-landslide tsunami in the Caribbean, in: Caribbean Tsunami Hazard, edited by: Aurelio, M. and Philip, L., World Scientific Publishing, Singapore, 43-65, https://doi.org/10.1142/9789812774613_0002, 2006.

McHugh, C., Seeber, L., Cormier, M.-H., Dutton, J., Çagatay, N., Polonia, A., Ryan, W. B. F., and Gorur, N.: Submarine earthquake geology along the North Anatolia Fault in the Marmara Sea, Turkey: A model for transform 
basin sedimentation, Earth Planet. Sc. Lett., 248, 661-684, https://doi.org/10.1016/j.epsl.2006.05.038, 2006.

McHugh, C., Seeber, L., Braudy, N., Cormier, M.-H., Davis, M. B., Diebold, J. B., Dieudonne, N., Douilly, R., Gulick, S. P. S., Hornbach, M. J., Johnson III, H. E., Mishkin, K. R., Sorlien, C. C., Steckler, M. S., Symithe, S. J., and Templeton, J.: Offshore sedimentary effects of the 12 January 2010 Haiti earthquake, Geology, 39, 723-726, https://doi.org/10.1130/G31815.1, 2011.

Moknatian, M., Piasecki, M., and Gonzales, J.: Development of Geospatial and Temporal Characteristics for Hispaniola's Lake Azuei and Enquillo Using Landsat Imagery, Remote Sensing, 9, 1-32, https://doi.org/10.3390/rs9060510, 2017.

Murakami M. and Tagami, T.: Dating pseudotachylyte of the Nojima fault using the zircon fission-track method, Geophys. Res. Lett., 31, L12504, https://doi.org/10.1029/2004GL020211, 2004.

Peng, Z., Gonzalez-Huizar, H., Chao, K., Aiken, C., Moreno, B., and Armstrong, G.: Tectonic tremor beneath Cuba triggered by the Mw8.8 Maule and Mw9.0 TohokuOki earthquakes, B. Seismol. Soc. Am., 103, 595-600, https://doi.org/10.1785/0120120253, 2013.

Perrin, C., Manighetti, I., Ampuero, J.-P., Cappa, F., and Gaudemer, Y.: Location of largest earthquake slip and fast rupture controlled by along-strike change in fault structural maturity due to fault growth, J. Geophys. Res., 121, 3666-3685, https://doi.org/10.1002/2015JB012671, 2016.

Possee, D., Keir, D., Harmon, N., Rychert, C., Rolandone, F., Leroy, S., Corbeau, J., Stuart, G., Calais, E., Illsley-Kemp, F., Boisson, D., Momplaisir, R., and Prépetit, C.: The Tectonics and Active Faulting of Haiti from Seismicity and Tomography, Tectonics, 38, 1138-1155, https://doi.org/10.1029/2018TC005364, 2019.

Prentice, C., Mann, P., Peña, L. R., and Burr, G.: Slip rate and earthquake recurrence along the central Septentrional fault, North American - Caribbean plate boundary, Dominican Republic, J. Geophys. Res, 108, 2149, https://doi.org/10.1029/2001JB000442, 2003.

Prentice, C., Mann, P., Crone, A. J., Gold, R. D., Hudnut, K. W., Briggs, R. W., Koehler, R. D., and Jean, P.: Seismic hazard of the Enriquillo-Plantain Garden fault in Haiti inferred from palaeoseismology, Nat. Geosci., 3, 789-793, https://doi.org/10.1038/ngeo991, 2010.

Pubellier, M., Mauffret, A., Leroy, S., Vila, M., and Amilcar, H.: Plate boundary readjustment in oblique convergence: example of the Neogene of Hispaniola, Greater Antilles, Tectonics, 19, 630648, https://doi.org/10.1029/2000TC900007, 2000.

Rolandone, F., Lucazeau, F., Poort, J., and Leroy, S.: Heat-flow estimates offshore Haiti in the Caribbean plate, Terra Nova, 32, 179-186, https://doi.org/10.1111/ter.12454, 2020.

Rosencrantz, E. and Mann, P.: SeaMARC II mapping of transform faults in the Cayman Trough, Caribbean Sea, Geology, 19, 690-693, https://doi.org/10.1130/00917613(1991)019<0690:SIMOTF>2.3.CO;2, 1991.

Saint Fleur, N., Feuillet, N., Grandin, R., Jacques, E., WellAccardo, J., and Klinger, Y.: Seismotectonics of southern Haiti: A new faulting model for the 12 January 2010 M7.0 earthquake, Geophys. Res. Lett., 42, 10273-10281, https://doi.org/10.1002/2015GL065505, 2015.

Saint Fleur, N., Klinger, Y., and Feuillet, N.: Detailed map, displacement, paleoseismology, and segmentation of the Enriquillo-
Plantain Garden Fault in Haiti, Tectonophysics, 778, 228368, https://doi.org/10.1016/j.tecto.2020.228368, 2020.

Scherer, J.: Catalogue chronologique des tremblements de Terre ressentis dans l'île d'Haïti de 1551 à 1900, in: Bulletin Semestriel de L'Observatoire Météorologique du Séminaire-Collège StMartial, Port-au-Prince, Haiti, 147-151, 1913.

Symithe, S. and Calais, E.: Present-day shortening in Southern Haiti from GPS measurements and implications for seismic hazard, Tectonophysics, 679, 117-124, https://doi.org/10.1016/j.tecto.2016.04.034, 2016.

Symithe, S., Calais, E., Haase, J.S., Freed, A.M., and Douilly, R.: Coseismic Slip Distribution of the 2010 M7.0 Haiti Earthquake and Resulting Stress Changes on Regional Faults, B. Seismol. Soc. Am., 103, 2326-2343, https://doi.org/10.1785/0120120306, 2013.

Symithe, S., Calais, E., de Chabalier, J. B., Robertson, R., and Higgins, M.: Current block motions and strain accumulation on active faults in the Caribbean, J. Geophys. Res., 120, 3748-3774, https://doi.org/10.1002/2014JB011779, 2015.

Taylor, F. W., Mann, P., Valastro Jr., S., and Burke, K.: Stratigraphy and Radiocarbon Chronology of a Subaerially Exposed Holocene Coral Reef, Dominican Republic, J. Geol., 93, 311332, https://doi.org/10.1086/628954, 1985.

ten Brink, U. S., Bakun, W. H., and Flores, C. H.: Historical perspective on seismic hazard to Hispaniola and the northeast Caribbean region, J. Geophys. Res., 116, B12318, https://doi.org/10.1029/2011JB008497, 2011.

ten Brink, U. S., Bakun, W. H., and Flores, C. H.: Seismic hazard from the Hispaniola subduction zone: Correction to "Historical perspective on seismic hazard to Hispaniola and the northeast Caribbean region," J. Geophys. Res., 116, 1-15, https://doi.org/10.1002/jgrb.50388, 2013.

Van Dusen, S. R. and Doser, D. I.: Faulting processes of historic (1917-1962) $\mathrm{M}>=6.0$ earthquakes along the northcentral Caribbean margin, Pure Appl. Geophys., 157, 719-736, https://doi.org/10.1007/PL00001115, 2000.

Wang, J., Mann, P., and Stewart, R. R.: Late Holocene Structural Style and Seismicity of Highly Transpressional Faults in Southern Haiti, Tectonics, 37, 3834-3852, https://doi.org/10.1029/2017TC004920, 2018.

Wessels, R. J. F.: Tectonic evolution, fault architecture, and paleofluid circulation in transpressive systems - southern Haiti, Doctoral Thesis of the Sorbonne University, 382 pp., available at: https://tel.archives-ouvertes.fr/tel-02484820v2 (last access: 27 August 2020), 2018.

Wessels, R. J. F.: Chapter 15 - Strike-Slip Fault Systems Along the Northern Caribbean Plate Boundary, in: Transform Plate Boundaries and Fracture Zones, edited by: Duarte, J. C., 375-395, https://doi.org/10.1016/B978-0-12-812064-4.00015-3, 2019.

Wessels, R. J. F., Ellouz-Zimmermann, N., Bellahsen, N., Hamon, Y., Rosenberg, C., Deschamps, R., Momplaisir, R., Boisson, D., and Leroy, S.: Polyphase tectonic history of the Southern Peninsula, Haiti: from folding-and-thrusting to transpressive strike-slip, Tectonophysics, 751, 125-149, https://doi.org/10.1016/j.tecto.2018.12.011, 2019.

Whipple, K. and Meade, B. J.: Orogen response to changes in climatic and tectonic forcing, Earth Planet. Sc. Lett, 243, 218-228, https://doi.org/10.1016/j.epsl.2005.12.022, 2006. 
Wiggins-Grandison, M. D. and Atakan, K.: Seismotectonics of Jamaica, Geophys. J. Int., 160, 573-580, https://doi.org/10.1111/j.1365-246X.2004.02471.x, 2005.
Zoback, M., Hickman, S., Ellsworth, W., and the SAFOD Science Team: Scientific Drilling Into the San Andreas Fault Zone - An Overview of SAFOD's First Five Years, Sci. Dril., 11, 14-28, https://doi.org/10.2204/iodp.sd.11.02.2011, 2011. 